\title{
3M Heavy Duty Roto Peen: Baseline Report Summary
}

\section{Topical Report \\ July 31, 1997}

\section{1}

Work Performed Under Contract No.: DE-FC21-95MC32260

For

U.S. Department of Energy

Office of Environmental Management Office of Technology Development 1000 Independence Avenue

Washington, DC 20585
U.S. Department of Energy

Office of Fossil Energy

Federal Energy Technology Center Morgantown Site

P.O. Box 880

Morgantown, West Virginia 26507-0880

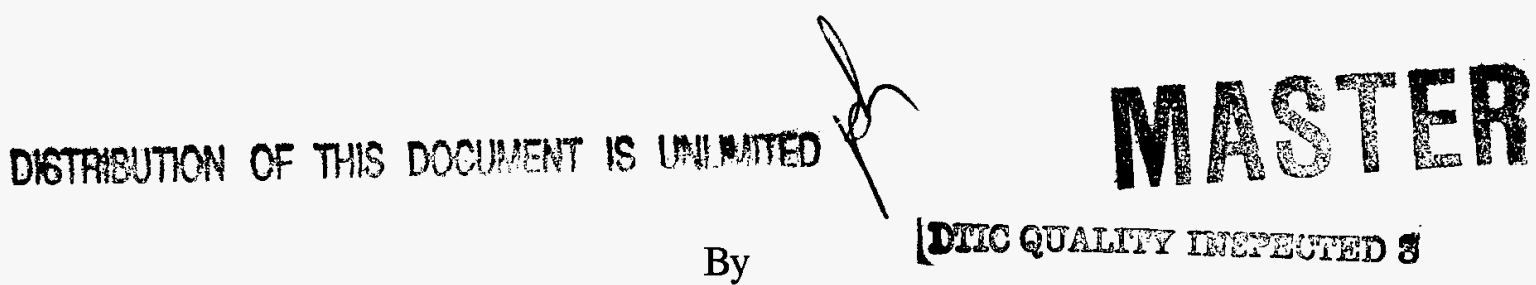

Operating Engineers National Hazmat Program 250 Airport Circle

Beaver, West Virginia 25813 


\section{Disclaimer}

This report was prepared as an account of work sponsored by an agency of the United States Government. Neither the United States Government nor any agency thereof, nor any of their employees, makes any warranty, express or implied, or assumes any legal liability or responsibility for the accuracy, completeness, or usefulness of any information, apparatus, product, or process disclosed, or represents that its use would not infringe privately owned rights. Reference herein to any specific commercial product, process, or service by trade name, trademark, manufacturer, or otherwise does not necessarily constitute or imply its endorsement, recommendation, or favoring by

the United States Government or any agency thereof. The views and opinions of authors expressed herein do not necessarily state or reflect those of the United States Government or any agency thereof. 


\section{SECTION 1 - SUMMARY}

\section{Technology Description}

The roto peen scaler allows for the selective removal of concrete substrates. The peen is a tungsten carbide shot brazed to a hardened steel rivet that is supported by a heavy duty flexible flap. The peens are coupled with a commercially available piece of equipment that is used to scabble or remove the concrete. The scabbled debris is then collected into 55-gallon drums by means of a vacuum system.

\section{Key Results}

The safety and health evaluation included noise and dust monitoring. Dust exposure was minimal, but noise exposure was significant. Further testing for each of these exposures is recommended because of the outdoor environment where the testing demonstration took place. Other areas of concern found were arm-hand vibration, ergonomics, heat stress, tripping hazards, electrical hazards, machine guarding, and lockout/tagout during maintenance activities.

\section{SECTION 2 - HEALTH AND SAFETY EVALUATION}

\section{General Safety and Health Concerns}

Safety and health issues of concern with the heavy-duty roto peen technology included: tripping hazards, electrical hazards, burn hazards from hot surfaces, rotating machinery, lockout/tagout, heat stress, ergonomics, arm-hand vibration, noise, dust, and communication.

\section{Industrial Hygiene Monitoring}

During the testing demonstration, sampling was conducted for dust and noise. In addition, the wet-bulb globe temperature was monitored, and observational evaluation was conducted for ergonomics and arm-hand vibration.

Ergonomically there is potential for muscle/back stress and/or injury to the knees. Arm-hand vibration was not quantitatively measured, but it was readily apparent that there was exposure to armhand vibration that could potentially cause problems such as Raynaud's syndrome.

Heat stress was monitored using wet-bulb globe measurements and worker physiological measurements such as blood pressure, pulse, and temperature. Work/rest regimen recommendations were made in accordance with ACGIH recommendations.

Personal air sampling for dust was conducted on the equipment operator, and area sampling was done at the head of the equipment. Personal and area sampling results were below allowable levels. Noise monitoring recorded a dose of $130.05 \%$ or an 8-hour TWA of $91.9 \mathrm{dBA}$. This exceeds the OSHA action level of $85 \mathrm{dBA}$ and the permissible exposure limit of $90 \mathrm{dBA}$. A hearing conservation program will be essential for anyone working with or around this equipment.

\section{Human Factors Interface}

The technology was evaluated for operator interface with Anti-C PPE including a full face 
air-purifying respirator. The operator reported some visibility problems while wearing the PPE due to the full face respirator. In addition, there was an increase in heat stress associated with the protective ensemble.

\section{SECTION 3 - TECHNOLOGY APPLICABILITY}

On observation, the technology did deposit some visible dust into the atmosphere. Air monitoring did not evidence an excessive dust level; however, the windy outdoor test environment was not representative of an enclosed work environment. The majority of the visible dust was seen the scabbling head was lifted, and near the vacuum system dust bags.

The technology itself would not be difficult to decontaminate. It could be considered a consumable at the completion of the project, but the equipment it was coupled with during the testing demonstration would have to be torn down to be decontaminated. This will not necessarily guarantee that decontamination for alpha will be complete. It will be difficult to survey for alpha contamination due to all of the small spaces in the equipment which are hard to reach with a probe.

\section{SECTION 4 - REGULATORY/POLICY ISSUES}

The site safety and health personnel where the heavy-duty roto peen technology is being used need to be concerned with safety and health regulations applicable to the issues discussed above. Regulations that will apply may include but not be limited to the following areas: housekeeping, electrical, hand and power tools, machine guarding, lockout/tagout, ionizing radiation, toxic and hazardous substances, noise, respiratory protection, P.PE, HAZCOM, HAZWOPER, and arm-hand vibration.

\section{SECTION 5 - OPERATIONAL CONSIDERATIONS \& RECOMMENDATIONS}

Recommendations for improved worker safety and health include good housekeeping, ergonomic training and awareness, a better vacuum hose clamping system, assessing the hand-tool for possible operation from a standing position, awareness of burn hazards associated with hot surfaces, guarding all moving parts, assuring proper vacuum adjustment for adequate air flow, using wing nuts and premarked rulers on parts requiring adjustments, a dead man switch on all equipment, and engineering, administrative, and/or hearing protection be used for compliance with the OSHA noise standard.

Due to the windy outdoor testing conditions, it is recommended that the noise and dust monitoring be conducted while the technology is in use in an enclosed environment. Since Level A or Level B PPE may be required for contaminants other than alpha radiation, it is recommended that the human factors interface for these levels of protection be conducted. Of concern is the ability of the equipment to continue to run without the operator's control. This could lead to serious injury for the operator or other workers in the area. A mechanism such as a dead man switch would address this potential for injury.

\footnotetext{
Research supported by the U.S. Department of Energy's Federal Energy Technology Center, under cooperative agreement DE-FC21-95MC32260 with the Operating Engineers National HAZMAT Program, 250 Airport Circle, Beaver, WW 25813, phone 304-253-8674, fax 304-253-7758. This report was prepared with the support of the US DOE; however, any opinions, findings, conclusions, or recommendations expressed herein are those of the author(s) and do not necessarily reflect the views of the DOE.
} 
M98002037

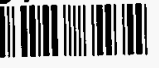

Report Number (14)DOع/mc/32260 - 5832

subl. Date (11) 19970731

Sponsor Code (18) $\triangle 0 \varepsilon / \varepsilon m ; \triangle O \varepsilon / F E, X F$

JC Category (19) UC-2000; UC-101, DOE/ER

DOE 